\title{
The comparative analysis of challenges to the national education systems in Bulgaria and Ukraine (on the example of the tourism and IT sectors)
}

\author{
Gesho Lyubenov ${ }^{1, *}$, Oleksandr Zyma ${ }^{2, * *}$, Hanna Brusiltseva ${ }^{2, * * *}$, Nadiya Dekhtyar ${ }^{2, * * *}$, and Nataliia Pohuda $^{2, \dagger}$ \\ ${ }^{1}$ Vocational High School of Computer Modeling and Computer Systems, 1 Studentska Str., Varna, 9010, Bulgaria \\ ${ }^{2}$ Simon Kuznets Kharkiv National University of Economics, 9A Nauky Ave., Kharkiv, 61166, Ukraine
}

\begin{abstract}
The article offers an overview of the global trends in education that have emerged during the 2020 economic recession; provides a retrospective analysis of the change in economic formations during the 1990s, which still influences the business environment and national education systems in post-socialist countries; analyses the structure of tourism flows in Bulgaria and Ukraine in the recent pre-crisis period; distinguishes the changes between local tourism markets in both countries and consequent demands to HEIs, training the workforce for domestic and international companies; outlines the IT services market in Bulgaria and Ukraine from the side of employment generating; points out the discrepancy between the requests to developers of IT solutions at the local level and the orders of transboundary corporations, which are the largest employers today for the economies in transition; presents the grouping of national economies by innovation performance according to the Global Innovation Index report; classifies non-material industries on the basis of potential for increasing added value and duplicating the product; indicates the restrictions of recreational capacity for the tourism infrastructure; highlights the disparity in clustering the world countries by absolute and relative Travel \& Tourism impact to GDP; substantiates the need for interdisciplinary approach in composing the curricula for specialities of the related industries; emphasises the existence of thresholds in the process of increasing the professional competence level. The relevance is grounded by the ultimate changes within the current structure of the global economy, as the sphere of higher education is quite significant in the international trade in services; the general paradigm of the theory of international economic relations is being modified now towards the refusal from the resources' inexhaustibility postulate; thus the research novelty consists in the implementation of supporting programmes and strategies in the field of higher education under the consideration of these trends.
\end{abstract}

\section{Introduction}

National education systems continue to play a significant role in the stability of socio-demographic processes and the creation of products that are competitive in the global market, and, accordingly, ensure the country's GDP. Unfortunately, certain negative experience has been shown in this field. In the last decade, the state concept of national education in Bulgaria and Ukraine has evolved towards a narrowly focused specialisation, as the labour market felt the need for niche-specialised professionals. Today, the opposite trend is being observed, provoked by innovators - an interdisciplinary approach in solving practical problems and lightning-fast adaptation to the latest information technologies, which has become acutely relevant during the economic recession of 2020 .

\section{Literature review and problem statement}

The literature we have used to corroborate our presumptions and findings is divided into three content groups. The

\footnotetext{
*e-mail: g.lyubenov@itpg-varna.bg

**e-mail: zima@hneu.edu.ua

***e-mail: anna.brusiltseva@hneu.net

****e-mail: nadiya.dekhtyar@hneu.net

$\dagger$ e-mail: pohuda.nataliia@hneu.net
}

first one gives a brief overview based on economic history and some retrospective issues explaining current trends in education and policy measures implied by national governments - as they seemed odd and unreasonable for the population. The second group discusses the current crisis in traditional education and the suggested trends to change its methodology and the third outlines practical examples of resolving the most acute problems in the field of tertiary education. Some works are analysed in detail to highlight the preconditions to our research of the national education systems in Bulgaria and Ukraine.

1. The aspects of divergence between the high and secondary school (or professional) education demand in different European countries are discussed by M. Mysíková and J. Večerník [1]. The prevalence in social status was informally proved by higher education in the transition countries in Eastern and Central Europe (the former USSR block and its trade partners), so the beginning of the 1990s, as the researches highlight, depicted an outstanding gap between the need for higher education degrees in the "western" and "eastern" national economies, despite the stagnation of the latter. In the next decade, the situation changed dramatically, 
but the gap between countries emerging from different socio-economic systems is still being noted. We suggest the following explanation for this fact.

Without understanding some type of "psychological inclination" to academic knowledge and ephemeral perspectives that should have opened up for a learned person with a scientific degree (in theory broken by further mid-nineties crisis in the former socialist states), revealing the reasons for the inefficient model of governmental expenditures and "clumsy" labour market altogether with lagging productive forces that did not meet market needs, is in vain. Echoes of the conceptual perception that the sphere of vocational and higher education should first of all create an exceptional image of the state and prove the primacy of its scientific achievements in all sectors (without exception!), and only then meet the needs of the most profitable sectors of the national economy, are still felt in post-socialist countries. On the one hand, this paradigm made it possible to preserve the national higher education system (of course, with some losses) during the most crisis periods of the independence establishment in transition economies; on the other hand, it decelerated significantly the accumulation of intellectual capital demanded by the market and the "mind shift" towards market business models. But without a brief historical discourse, it is inappropriate to discover the processes that took place in the regulation of higher education in Bulgaria and especially Ukraine, where it was much more difficult to switch to a new economic model since the analysis of the strategy effectiveness based on efficiency and profitability simply did not work. According to O. Dvouletý [2], different patterns of economic (and entrepreneurial) behaviour might have influenced the protracted recession.

The study [1] covers 30 years, thus encompassing the main trends in their formation. The most interesting outcomes, given the topic of this article, outbreak some settled concepts. First, the authors prove the theoretical statement claimed by G. S. Becker in 1975 that "marginal returns to education fall as the proportion of the population with higher education rises". Closer to modern conditions, the empirical explanation should take into account not only the growth of production with high added value (a logical repercussion of the labour force intellectualisation) but also the flow of a worker's efforts from the production sector to recreation. The learned person (especially if increasing the average household's income as the result of higher salaries compared to the unskilled worker) will search for more possibilities to rest and diminish the working hours, than for the ways to increase productivity. The desire to get away from routine work, which in theory should stimulate the invention of more advanced technologies, in reality, has transformed into outsourcing and the search for subcontractors with low rates, often in poorer countries. Indirectly, it has led to opening the borders for unskilled labour force (ended in multiple social problems due to uncontrolled migration) and the emergence of a new stratum of employees - distant/freelance workers in knowledge-based industries. Digitalisation and 24/7 online access have led to equalization of wages to the minimum offered by the poorest countries (where workers are qualified enough for delegable jobs. Transnational companies prefer to educate their part-time workers themselves and pay less than hire residents from the headquartering region (with higher rates and strict labour legislation). In this case, the governmental support of the national education system is unprofitable.

Second, the level of returns to tertiary education differs significantly across European countries. In general, it is higher in the regions with low GDP and is lower in the most developed ones. Building the hypothesis empirically, we could hardly assume it. Scandinavian states are the most profitable, with a decent level of tertiary education, and namely, they showed the worst results. So, is the first statement irrefutable? Under these conditions, the governments should decrease funding to the national education systems, shouldn't they? On the contrary, the high-income economies proceed to guarantee free or sponsored education not only to their citizens but to foreigners as well. We suggest that simplified regression or correlation models are not enough to reflect all interrelations between the state income, the quality of life of the local population and the importance of R\&D and academic education. The highest possible share of educated people may crush the social unrest, so many governments prefer to pay extra for the piece than for civil conflicts resolution.

Third, the negative impact of tertiary education on labour productivity has been found only in the "west" group - the developed countries. It seems that economies in transition have some auxiliary period during which they need to boost R\&D, GDP and the share of the population enrolled by tertiary education, until it becomes unprofitable in terms of labour productivity. In the globalised world with free resources transfer, it sounds strange, but M. Mysíková and J. Večerník substantiate their findings by trusted statistical tests.

The paper by K. Stefanova and N. Velichkov [3] covers a shorter period and less extent of the central and east EU countries and is also devoted to the efficiency of tertiary education expenditure. They say that human capital obtains a positive effect on the long-term economic growth, so its profitability should not be assessed for the short-term strategies. The 2018 CEE statistics represents the prevalence of tertiary education in employment among youth - on average, $82.9 \%$ of university graduates within the 25-29 age group managed to find a job, and only $77.7 \%$ of their counterparts who had stopped at 
secondary education were hired (K. Stefanova and $\mathrm{N}$. Velichkov, as opposed to the other cited papers, used employment ratios instead of personal income criterion, in the efficiency evaluation). The Europe 2020 Strategy aimed at $40 \%$ share of the total population with tertiary education; Czechia, Estonia, Latvia, Lithuania, Poland and Slovenia have already reached it. But even with the other CEE member states with lower rates, the EU average for age group $30-34$ made $40.7 \%$ in 2018 . On the contrary, the authors of [3] try to argue the positive effect of higher education attainment on economic development (it might not be entirely correct to empirically extrapolate their findings to other EU countries).

2. F. Balázs [4] discovers the importance of various competencies in global labour market forecasts, and names two skills that will be in demand. They are complex problem solving and cognitive flexibility, which should shift formal tertiary education intended on professional competences forming to communication and emotional intellect, supplemented by foreign languages proficiency and "telecollaboration" - the ability to communicate distantly. Note that this is a general trend in the reform of national education systems, which at first looked imposed from the outside, especially for countries with a traditionally rigid approach to organizing the educational process and control of knowledge. This approach can even harm if it is used irrationally and does not take into account the specifics of the so-called "classical specialities" (mainly natural sciences, where a student must accumulate the minimum set of concepts, without which building his/her hypotheses and applying scientific search methods is impossible). The law-based unification of the ratio between the class and individual work in Ukraine happened to be a bad experience, a fortiori, the ECTS system did not set so strict recommendations.

The concept of increasing the value of soft skills is not rejected by most researchers, but practical evidence proves that they must be supported by professional skills (the latter may be unique for each company - of course, it exaggerates the educational curriculum; some core niche professional issues are the trade secret and thus cannot be granted to the university programme) - so, the real task is to find the proper equilibrium between technical competences and communication. K. N. Tang [5][5] discovers the current attitude toward soft skills maintenance among teachers. The researcher insists that communicative, creative thinking and other skills are more in favour among the employers as they are transferrable through many jobs. T. Bolli and F. Pusterla [6] have decided to test the significance of IT skills in managing business processes and intranet communication. They have found out that the first is much more important for companies' performance (the hypothesis was tried on high-education workers).

V. Lukesch and T. Zwick [7] raise the problem of competence between academic and vocational education. Close to work [1], the authors use income data for workers with tertiary education compared to those who finished vocational schools and try to find a correlation between the academic degree and higher personal income (their research covers only Germany). The outstanding experience of the German national education system is a dual apprenticeship, thus the demand for genuine academic education is traditionally lower than in other EU countries, which should be taken into account. When the other countries only started to discuss the possibility of merging vocational schools and classical HEIs, Germany had gained a unique practice of preparing graduates ready to return invested funds (expenditures on education) immediately. More than that, close cooperation with the real sector enterprises keep HEIs from spending extra money on professional equipment and training laboratories, which can be useful in the preliminary stages, when getting acquainted with the technological process in general, but is not able to copy the entire technological cycle. The institutions issue "the tertiary vocational education certificate", which is recognised by many companies and guarantees employment. Also, the system of vocational certification and academic degrees are embedded into the unified system of educational levels, which may seem too complicated for foreigners and often revokes the international nostrification of vocational degrees, but is very popular within the country as provides for multiple combinations of training methods. In general, V. Lukesch and T. Zwick found out, that there is no significant difference in earnings between the groups of students who graduated from vocational schools and traditional HEIs of the matched levels of education. Unfortunately, this experiment cannot be carried out in its pure form in other countries, since the results are based precisely on the uniqueness of the German education system. On the other hand, the achieved absence of an income gap and, which is even more important, in social status creates fewer prerequisites for social tension in society, especially among ambitious youth.

Studying tertiary education, one must not forget that school (secondary) education creates - or does not create - its sound background. T. Meyer and S. L. Thomsen [8] are discussing the problem of the duration of university preparatory schooling. In Germany, it had taken 13 years, and was shortened to 12 years in the mid-2000s. The main apprehension stakeholders having concerned about, had been the curriculum that would not have been changed. It turned out that pupils were able to finish the curriculum in less time and proceed with their studies at HEIs with slight difficulties, which were dissipated 
after the transition period had been completed. We will come back to this issue later when considering a similar problem with the reduction in the length of schooling in Ukraine.

Long-term schooling was uncharacteristic for postsocialist countries, where the accepted number of years had equalled 10. The secondary school had not formally been divided into grades, the pupil had been enrolled at the age of 6-8 in the 1st grade and then had graduated from the 10th grade (receiving full secondary education and being able to enter the HEI), or from the 9th grade (entering vocational schools). The administrative economics routine had prepared skilled employees as soon as possible, as the labour market had been controlled and the level of unemployment had been the lowest (to fulfil this goal, the practice of normative hiring and sending graduates to distant geographic regions had been used). The transition period in the mid1990s introduced the 11th grade (with the simultaneous cancelling of the 4th one - pupils seemed to "jump over" it), and in the short run schooling education was prolonged to full eleven and then twelve years. One of the reasons could be high unemployment and the need to reduce the load on local labour markets which began to suffer from oversupply as the real sector was ruined in multiple industries. T. Meyer and S. L. Thomsen say that the reduction of schooling was aimed to help students start their professional career one year earlier. The reform was initiated in times of global economic expansion and seemed quite logic (further world economic stagnation of 2008-2009 was not forecasted before).

V. Vandenberghe [9] explains the need to shorten the duration of tertiary education by population ageing, the elders' demand of goods and services and consequently - the growth of educated youth who will produce GDP and will be able to take loans earlier. Simultaneously, the duration of part-time education and professional training should strengthen. It seems that the threat of unemployment seems negligible compared to decreasing the age of potential consumers who must have become completely legally capable.

3. The market economy is remarkably quick to respond to consumer demands. If some product or service is not yet available, but its vision is formed and formalized in specific requests, innovative firms start production if the profitability forecasts are at least a bit positive. MOOCs (Massive Open Online Courses) have gained their popularity far before the 2020 pandemic. The new time-saving model of getting fragmentary highly-specialised skills from various geographically dispersed providers solves multiple challenges of contemporary transboundary employees. As in the case of any innovation, there was no need to control and predict its development before mass involvement. In 2020, MOOCs became a competitive alternative to traditional academic and vocational education. Within the network of secondary schools and HEIs, so-called intrinsic MOOCs - or massive closed online courses platforms (opened only for the enrolled students) emerged. Some educational institutions managed to introduce the new technology quickly, the others lacked the minimal set of human and technical resources - and are close to losing their students. But it is obvious that the inspiration and experience of MOOCs have been embedded into the current offline structures and thus need more research of their principles and efficiency.

A. Holzweber [10] pays attention to motivation triggers in e-learning. The role of a teacher is merely to facilitate than to transfer knowledge, but some scientific disciplines need a specific approach. Namely, A. Holzweber discerns foreign language lessons, which are traditionally based on face-to-face communications in teaching. H. W. You [11] studies the individual student's perception and the ways of successful MOOCs' completion, and introduces the terms "perceived usefulness" (contribution to personal skills via certain technologies) and "perceived ease of use" (the appreciation level of innovative educational technologies). The author uses the threat factor among the others when estimating the students' readiness to get knowledge online; this viewpoint is rare as the majority of researches pay attention predominantly to technical aspects. Nevertheless, the factor of psychological non-perception must be evaluated, especially within the framework of long-life learning involving people of different ages and from various backgrounds.

A. Griva, C. Thanopoulos and S. Armakolas [12] consider different stages of the educational process as a single cycle of knowledge acquisition and state that information technologies should take into account the specificity of each stage. Information coding is a principal intermediary process at transferring the knowledge from a teacher to a student, and the learning environment, either offline or online, must be created in the best way to support it. As European Commission distinguished in 2018 four types of digital skills (universal ones, for everyday life; skills for the labour force; skills for ICT professionals; educational ones), the curriculum competencies have to be classified according to the content of these groups and included into the learning process. R. A. Karim et al. [13] single out mobile learning technologies, which are expected to surpass applications for other devices.

O. Dvouletý [2] emphasises the concept of open innovation, stimulating entrepreneurship and subsequent economic growth. In work [14], the business models of transforming the national education based on the shift from core state institutions to private establishments are revealed, a franchised certificate 
programme from a reputed overseas university, education start-ups and hubs with curricula for the predefined stakeholders (such as local and foreign communities or commercial partnerships), among them. Ukraine plans to implement the first option to some extent since 2021, by legalizing accreditation of national educational institutions by foreign certification centres (their list is determined at the legislative level, in the Decree of the Cabinet of Ministers of Ukraine No 811 of 09.09 .2020 ).

\section{The aim and objectives of the study}

The current research aims to substantiate the interconnection between the provision of the country's residents with educational infrastructure (with special emphasis on tertiary education) and the potential of the national economic system. Not only short-term factors of personal income and the current state of the labour market but also the accumulation of intellectual capital and a reliable base for the R\&D large-scale projects should be taken into account when planning state funding for educational institutions. The structure and logic of the presented paper consist of three blocks of interrelated challenges that the global service industry has faced recently. The first section covers the challenges to the traditional education system in the field of tourism, which have arisen from the unforeseen restructuring of the global business model; the second section is devoted to the analysis of the companies' interaction in the tourism and IT industries, and how this affects the curricula content of related knowledge brunches; the third section highlights the problems that objectively appear due to the new trends in the global market, but could be hardly resolved by educational institutions on their own without the state support.

\section{Challenges to academic tourism education related to the global economic crisis}

The creation of travel services requires the participation of companies from a wide variety of industries. Within the framework of this study, we will consider options for interdisciplinary cooperation and attempt to assess the mutual influence of different areas of activity using the example of an interaction between tourism and the IT sector. When having prepared this article (December 2020), we were not able to apply to the annual official statistics (as it had not yet been published) covering the maximum period of the crisis. For the indicators below, the 2019 figures are mainly focused on, however, it should be clear that significant adjustments are possible in the next year. However, they will affect more dynamics and absolute values than the structure of the national economy, which depends on business practices and mode of cooperation, which usually take several years to change. Table 1 contains the main indicators of the tourism economy state $[15,16]$.

By the absolute figures, the volumes of the tourist economy of Ukraine exceed in most cases the similar in- dicators in Bulgaria, which can be explained, besides, by the area difference of the two countries.

In the pre-crisis period, the impact of tourism on Ukraine's GDP exceeded the output of the recreational industry in Bulgaria by 1 US\$ bn. In terms of employment, Ukraine exceeded Bulgaria by more than 2.6 times (with an average employment of about 330 thousand people per year, while in Bulgaria just over 120 thousand jobs were created). The same is true for the absolute indicators of tourist flows: Ukraine's foreign trade turnover in value terms exceeded Bulgaria's indicator by 1.4 times (9.7 and 6.9 US\$ bn, respectively), and quantitatively - by 2.6 times (41.3 and 15.5 million visits). The consumption of tourism services in the domestic market was also 4.4 times higher in Ukraine (4.87 versus 1.11 US $\$$ bn), and its contribution to the country's GDP was 2 times higher. However, if we analyse the structural and relative indicators, then at a larger scale, the tourism economy in Bulgaria functioned more efficiently than in Ukraine.

Firstly, Bulgaria's foreign trade balance is positive, in value and quantity (the country earned from exports by 2.6 US\$ bn more than its citizens spent on travel abroad, and accommodated foreign citizens by 2.6 million more, than the residents of Bulgaria went on vacation outside the country). Citizens of Ukraine, on the contrary, spent on foreign travel by 5.3 US\$ bn more than national travel companies earned from exports, and the total excess of the outbound flow over the inbound one made 12.9 million visits. The specific contribution of tourism production to GDP, employment of the population and especially the total export of goods and services $(11.2 \%)$ in Bulgaria are higher than in Ukraine. The specific income per one foreign tourist in Bulgaria is approximately US\$ 530, while in Ukraine only 155 US\$. Although the costs of one tourist travelling abroad are also higher in Bulgaria US\$ 330 versus 275 in Ukraine. The three-sectoral structure of tourist flows in Bulgaria is distributed in favour of exports $(60 \%)$, the costs of imports are twice the consumption of residents in the domestic market. In Ukraine, the share of export earnings is minimal (15\%), more than $50 \%$ comes from imports, consumption in the domestic market has been gradually increasing recently and in 2019 it was $35 \%$. This rise in domestic demand was caused by a deterioration in household earnings, as people with upper middle income prefer to travel abroad.

The average world ratio is distributed in favour of the domestic market (50\%) and approximately equally (20$22 \%$ each) between imports and exports. Interestingly, in monetary terms, the world balance of foreign trade in tourism services is positive (148.5 US\$), which may indicate an almost parity distribution of income and costs between states at the global scale, while the outbound flow exceeds the inbound one by 131.5 million visits to foreign countries. It can be assumed that, in general, the outbound flow is less expensive; the average "global tourist" spends more overseas than his/her country earns on foreign tourists. This is confirmed by the calculated data: earnings per arrival made US\$ 1 160, while costs per departure - US\$ 964. The contribution of both Bulgaria and Ukraine to the absolute indicators of the global market is 
Table 1. Comparative indicators of tourism economics in Bulgaria, Ukraine and the world

\begin{tabular}{|c|c|c|c|c|c|c|c|}
\hline \multicolumn{2}{|c|}{ Indicators, 2017-2019 average } & Bulgaria & Ukraine & World & Ratios & Bulgaria & Ukraine \\
\hline \multirow{2}{*}{$\begin{array}{l}\text { Direct contribution } \\
\text { to GDP }\end{array}$} & US\$ in bn (real prices) & 2.15 & 3.08 & 2669.60 & $\%$ of WT & 0.08 & 0.12 \\
\hline & share of total GDP, $\%$ & 3.30 & 2.15 & 3.16 & $\%$ of WT & - & - \\
\hline \multirow{2}{*}{$\begin{array}{l}\text { Direct contribution } \\
\text { to employment }\end{array}$} & thousands of jobs & 123.04 & 329.04 & 116734.33 & $\%$ of WT & 0.11 & 0.28 \\
\hline & $\begin{array}{l}\text { share of total employ- } \\
\text { ment, \% }\end{array}$ & 3.88 & 2.01 & 3.71 & $\%$ of WT & - & - \\
\hline \multirow{2}{*}{$\begin{array}{l}\text { Domestic Tourism } \\
\text { Spending }\end{array}$} & US\$ in bn (real prices) & 1.11 & 4.87 & 4011.37 & $\%$ of WT & 0.03 & 0.12 \\
\hline & share of total GDP, $\%$ & 1.62 & 3.27 & 4.66 & $\%$ of WT & - & - \\
\hline \multirow{4}{*}{$\begin{array}{l}\text { Outbound T\&T } \\
\text { Expenditure } \\
\text { (Imports) }\end{array}$} & $\begin{array}{l}\text { number of departures } \\
\text { (thousand)* }\end{array}$ & 6464 & 27124 & 1534054 & $\%$ of WT & 0.42 & 1.77 \\
\hline & US\$ in bn (real prices) & 2.14 & 7.49 & 1478.20 & $\%$ of WT & 0.15 & 0.51 \\
\hline & $\begin{array}{l}\text { share of total imports, } \\
\%^{*}\end{array}$ & 5.46 & 11.88 & 6.49 & $\%$ of WT & - & - \\
\hline & share of total GDP, $\%$ & 3.29 & 5.24 & 1.76 & $\%$ of WT & - & - \\
\hline \multirow{3}{*}{$\begin{array}{l}\text { Visitor Exports } \\
\text { (Foreign spending) }\end{array}$} & number of arrivals & 9078 & 14167 & 1402585 & $\%$ of WT & 0.65 & 1.01 \\
\hline & US\$ in bn (real prices) & 4.80 & 2.20 & 1626.74 & $\%$ of WT & 0.29 & 0.14 \\
\hline & $\begin{array}{l}\text { share of total exports, } \\
\%\end{array}$ & 11.17 & 3.32 & 6.71 & $\%$ of WT & - & - \\
\hline \multirow{2}{*}{$\begin{array}{l}\text { Trade Balance } \\
\text { (Exp - Imp) }\end{array}$} & US\$ in bn (real prices) & 2.65 & -5.29 & 148.53 & $\%$ of WT & 1.79 & -3.56 \\
\hline & $\begin{array}{l}\text { visits, arrivals - depar- } \\
\text { tures (thousand) }\end{array}$ & 2615 & -12957 & -131470 & $\%$ of WT & -1.99 & 9.86 \\
\hline \multirow{2}{*}{$\begin{array}{l}\text { Total Trade } \\
\text { Turnover (Exp + } \\
\text { Imp) }\end{array}$} & US\$ in bn (real prices) & 6.94 & 9.69 & 3104.94 & $\%$ of WT & 0.22 & 0.31 \\
\hline & $\begin{array}{l}\text { visits, arrivals + depar- } \\
\text { tures (thousand) }\end{array}$ & 15542 & 41291 & 2936639 & $\%$ of WT & 0.53 & 1.41 \\
\hline \multirow{5}{*}{$\begin{array}{l}\text { Total tourist flow } \\
\text { (exports }+ \text { imports } \\
+ \text { domestic } \\
\text { tourism) }\end{array}$} & US\$ in bn (real prices) & 8.04 & 14.55 & 7116.31 & $\%$ of WT & 0.11 & 0.20 \\
\hline & $\begin{array}{l}\text { Share in the total } \\
\text { tourist flow, } \% \text { : }\end{array}$ & 100 & 100 & 100 & difWA & _ & _ \\
\hline & Domestic Tourism & 13.7 & 33.4 & 56.4 & difWA & -42.6 & -22.9 \\
\hline & $\begin{array}{l}\text { Outbound T\&T Ex- } \\
\text { penditure }\end{array}$ & 26.7 & 51.4 & 20.8 & difWA & 5.9 & 30.7 \\
\hline & Visitor Exports & 59.6 & 15.1 & 22.9 & difWA & 36.8 & -7.7 \\
\hline \multirow[t]{2}{*}{$\begin{array}{l}\text { International } \\
\text { Tourism Efficiency }\end{array}$} & $\begin{array}{l}\text { earnings per arrival, } \\
\text { US\$ }\end{array}$ & 0.528 & 0.155 & 1.160 & $\mathrm{~N} / \mathrm{W}$ & 0.46 & 0.13 \\
\hline & $\begin{array}{l}\text { costs per departure, } \\
\text { US } \$\end{array}$ & 0.332 & 0.276 & 0.964 & $\mathrm{~N} / \mathrm{W}$ & 0.34 & 0.29 \\
\hline
\end{tabular}

* World Bank data, 2017-2018 average; \% \& of WT - share in the World Total; difWA - difference from the World Average; N/W - National to World ratio

extremely low and does not even reach $0.5 \%$. Assuming that about 200 national economies take part in world economic relations, i.e. independent countries and territories with special status (WTTC collects data on 162 of them), then theoretically, each such unit accounts for an average of $100 \% / 200=0.5 \%$. Suppose that only 150 countries participate in global tourism, so the share of possible participation will increase to $0.67 \%$. Bulgaria has almost reached this margin in terms of the number of foreign visits (international arrivals if we use the UNWTO terminology) $-0.5 \%$ of the global flow, foreign trade turnover is $0.53 \%$ of the world indicator, also in quantitative terms.

Thus, further development of the domestic infrastructure for receiving foreign tourists and stimulating the domestic market can be called a priority development for the national tourism economy in Bulgaria, while in Ukraine the export sector is a problematic one, which sagged after the start of the anti-terrorist operation in part of the eastern territories in 2014. But even earlier, there was an adverse trend of increasing the negative balance of tourist flows, the scale of which was much more significant than official statistics showed. With the increasing popularity of individual tourism and the improvement of software products for self-organised tours, fewer people turn to travel agents for intermediary services, which also makes it difficult to track visits and especially costs at the place of stay. Thus, the different needs of both travellers and companies that create tourism services for specific local markets lead to completely different specialisations for application developers and training programs. For guaranteed employment in Ukraine, a university graduate with a degree in Tourism must have different knowledge and skills than a future employee of a travel company in Bulgaria. In Ukraine, most companies work to organise outbound trips, while in 
Bulgaria the market demands differ completely. Accordingly, local companies need fundamentally different IT solutions. If Ukrainian SMEs are not individual consumers of specialised software, confining themselves to the content within corporate accounts on aggregating portals and performing, in general, unified business processes, then enterprises attracting and accommodating tourists in their region need a more diverse product. Besides, the local information infrastructure must be maintained at a decent level, so the customers of large projects are both local municipalities and governmental institutions. In Bulgaria, the collection of statistical data on tourist flows is more detailed than in Ukraine - not only annual but also monthly indicators are processed. In Ukraine, the seasonality of visits is not confirmed by any official reports of the host companies. A detailed system of official statistics requires sophisticated software to automate data collection, in addition to the time required to prepare them for the respondent companies.

In general, the more diverse IT products are used, the more jobs are created in the industry, not only directly for development, but also routine maintenance and upgrades, as well as on-site staff training. If it is possible to buy a finished product or order an individually developed application via outsourcing, even in another region of the world, then it is difficult to organise high-quality operational service remotely, taking into account local specifics, and large companies with sufficient funds begin to hire local specialists, although a few years ago there was a tendency to place orders in countries with minimum wages and marginal qualifications. Both in Ukraine and Bulgaria, the trends in the IT labour market are similar: the majority of local specialists work in outsourcing for large foreign companies, mainly in North America and some countries of Western and Northern Europe, and Israel. Local technical universities are less focused on the needs of national customers, following the current trends of foreign employers (after all, an important criterion for the success of a training program is the employment of its graduates). It would seem that there should be no contradictions, because software products are generally universal for the same industries, and the global network infrastructure provides $24 / 7$ communication between the developer and the consumer. However, the use of off-the-shelf software is highly dependent on hardware, and while developed countries can afford the most innovative hardware, middle-income ones lag in this process. Obsolescence/amortisation of computer equipment sets in quickly, in six months or a year, at most two (which is also fuelled by the hasty updating of hardware and software by manufacturers, who in turn have to reckon with the effect of expanded reproduction to increase profits) - and it stipulates a paradox when local companies from the leading country in the development of this or that software do not purchase it from the customer company, although there are more than enough local specialists who are ready to arrange promotion and maintenance. Excluding the cases of order fulfilment for individual markets and control over the non-proliferation of finished products outside the contract, the reason usually becomes the obsolescence of equipment among the majority of active users of IT services, especially households and SMEs. Linux-based systems are less resource-demanding, therefore, despite the increased complexity of training for the average user, they are gradually replacing Windowsbased systems from the local markets. In Bulgaria, there is not even an official representative of Certiport yet (the office in Macedonia is in charge) - an organization that supervises the preparation and passing of professional exams for software products certificates of famous world developers, including Adobe, Autodesk, Microsoft and Unity.

$\mathrm{N}-\mathrm{iX}$ company has conducted a comparative analysis of the IT outsourcing market in Bulgaria and Ukraine. The quality indicators for training specialists are higher in Ukraine, while the general state of the business environment and infrastructure is higher in Bulgaria. In comparison with other countries of the world, according to international ratings, in terms of the level of innovative development, two countries are in the same classification group (table 2) [17-20].

In the 2020 GII report, an interesting classification of economies is given: the countries are clustered by the level of income and expectations to innovate, empirically dependent on it (table 3). In the GII report, national economies were prior classified by income groups and then divided into three categories by the level of the innovation. To facilitate the comparison between different income groups, we have normalised the GDP per capita (in terms of PPP) within each of the 12 categories. The range of the normalised indicators does not exceed 1.52 units except for one subgroup, so we may state that the states implementing similar innovative policies are approximately homogeneous by their citizens' annual income. This double grouping aimed to highlight the countries which earn nearly the same budgets as their counterparts but prefer to spend funds on innovative development.

On the other hand, some countries may receive the highest income within their group, but neglect innovations. Both Bulgaria and Ukraine are innovative leaders in their categories and are distinguished by the highest purchase power parity, which makes the national workforce and infrastructure maintenance cheaper than the competitors suggest.

The 2019 report says that Ukraine "has the world's second lowest Big Mac price of \$1.64, cost of living is $58.29 \%$ lower than in the United States" [[18], p. 9]. The country occupies the 4th position in the World Bank Tertiary Education Enrolment Index and ICT is the 3rd largest export service industry [[18], pp. 10, 19].

We will not focus on the tourism market and related sectors decline caused by the global crisis in 2020. During any historical era, periods that are unfavourable for a particular industry inevitably arise. Moreover, in countries that are not involved in military conflicts on their territory (the majority of them in the aggregate), the tourist infrastructure has not suffered, i.e. there was no physical destruction of recreational facilities and, if this term can be applied to the service sector, means of labour and objects of labour were kept untouched. Even intangible services are created using tangible media - for example, to write a computer program, you need special equipment - hard- 
Table 2. Comparative indicators of Bulgaria and Ukraine in the field of IT (most figures from 2019 reports)

\begin{tabular}{l|c|c}
\hline Indicator & Bulgaria & Ukraine \\
\hline IT export & 2.5 US\$ bn \\
IT hubs (number of cities) & Sofia, Plovdiv, Varna, \\
Burgas (4) & $\begin{array}{c}\text { Kyiv, US\$ bn } \\
\text { Lviv, Kharkiv, } \\
\text { Odesa, Dnipro (5) } \\
184700\end{array}$ \\
IT professionals & 70000 & 580 \\
IT companies listed on Clutch, units & 2130 & 15000 \\
Annual ICT graduates & 2000 & moderate \\
English proficiency & high & 99.8 \\
Literacy rate, \% of adult population & 98.4 & 5 \\
Best programmers by SkillValue, place & 12 & 6 \\
Programmers ranking by TopCoder, place & 20 & 64 \\
The "Ease of doing business rank" (Doing Business 2020) & 61 & 20 \\
AT Kearney Global Services Location Index, rank & 17 & 52 (41.47) \\
Global Talent Competitiveness Index 2020, rank (score) & 44 (45.76) & 45 \\
Global Innovation Index 2020, rank & 37 & Upper middle-income \\
Economies group by GII & Lower middle-income \\
\hline
\end{tabular}

ware; to arouse the interest of potential visitors to a tourist object (physical form) or an event (non-material form), it is necessary to carry out preparatory work, and it is not based solely on information exchange. Media content creation is also impossible without physical equipment. Therefore, the crisis faced by many service providers is a crisis of a lack of demand. Its nature is somewhat different from the crisis of overproduction when demand falls due to market saturation - i.e. buyers satisfied their needs and stopped at some point to "recycle" the purchased product or service.

2020 is characterised by an almost complete absence of demand, brought to the final stage, namely purchases (the flow of cash and their equivalents from the consumer's wallet to the manufacturer's account), with a simultaneous desire to still use "prohibited products". The market received a peak intensity of the so-called desire to buy, especially at the lockdown beginning, when the population had enough funds and rather optimistic forecasts were made in the medium term. If we simplify the way of thinking of the average consumer, then the following logical chain emerges: "I have money that I planned to spend on travel, i.e. pleasure - a travel and many types of recreation within daytime availability were banned (shopping and entertainment events ) - the desire to receive emotional relaxation and positive emotions remained unfulfilled - what can I do now (read, what I can buy immediately) to compensate for this desire?" That is why the beginning of the quarantine period was characterised by an unprecedented boom in sales of various consumer commodities, especially via online stores and those trading companies that were able to establish prompt home delivery in compliance with local sanitary and epidemiological standards established at the legislative level. When the first peak of positive expectations passed and the lockdown period was forecasted for a longer period, but funds from the tertiary sector were still sufficient, sales of online content (non-material products) began to grow.

The trend towards intangible consumption was especially clear on open educational platforms and other re- sources with educational and cultural content. There are no aggregated official data, but we assume that the costs of servicing the MOOCs, cultural and art institutions that provided online access to their collections for more than half a year were financed partly from state budgets and partly by sponsorship contributions from multinational companies. This decision lay in the psychological, not economic, scope: it was necessary to reduce the emotional stress that arose in countries with particularly stringent quarantine measures. According to preliminary calculations, it should have been cheaper than organizing a system of psychological support with the involvement of qualified highly paid specialists. Also, many workers whose professional activities were suspended for a long time began to search for quick retraining options. The commercialization of the online educational services market started, but the proposals came mainly not from academic institutions, but from freelancers, representatives of the so-called "digital professions" that have become so popular, some companies that decided to cut costs by firing full-time employees and trained freelancers from the regions with lower pay rates; finally, as in any crisis period, fraud retraining courses were offered in a state of initial confusion.

Academic institutions, despite the availability of sufficient material and technical background and the accumulated amount of knowledge, were unable to reorient themselves to the emerging free niches (which could be considered as temporary mini-projects) partly due to the bureaucracy and sluggishness - traditional characteristic of classical universities, partly due to regulatory restrictions in the provision of services to third parties which could not be signed to the standard contract. The crisis for universities began later, with the start of the new academic year (September 2020). By this time, the funds of the state budget gradually dried up due to the reduction in GDP and, accordingly, the question of cuts in funding for nonpriority sectors, and the inflow decay of students of fulltime education (many began to equate distance learning with part-time) and foreign students - these two flows have been traditionally the main sources of funds formation for 
Table 3. Grouping of national economies by innovation performance (based on the income level)

\begin{tabular}{|c|c|c|c|}
\hline \multirow{2}{*}{$\begin{array}{l}\text { Income } \\
\text { status }\end{array}$} & \multicolumn{3}{|c|}{ Correspondence with the level of development } \\
\hline & Above expectations & In line with expectations & Below expected \\
\hline $\begin{array}{l}\text { High- } \\
\text { income }\end{array}$ & $\begin{array}{l}\text { 1) Singapore: 1.723; 2) Ireland: } \\
\text { 1.459; 3) Switzerland: } 1.206 \text {; } \\
\text { 4) United States: 1.093; 5) Hong } \\
\text { Kong, China: 1.074; 6) Nether- } \\
\text { lands: 1.004; 7) Denmark: } 1.001 \text {; } \\
\text { 8) Germany: 0.951; 9) Swe- } \\
\text { den: 0.944; 10) Canada: 0.873; } \\
\text { 11) Finland: 0.862; 12) United } \\
\text { Kingdom: 0.824; 13) France: } \\
\text { 0.819; 14) South Korea: 0.734; } \\
\text { 15) Japan: 0.729; 16) Israel: 0.706 } \\
\text { (Mean GDPpc-57 325.59 US\$; } \\
\left.\text { range }_{\text {norm }}-1.017\right)\end{array}$ & 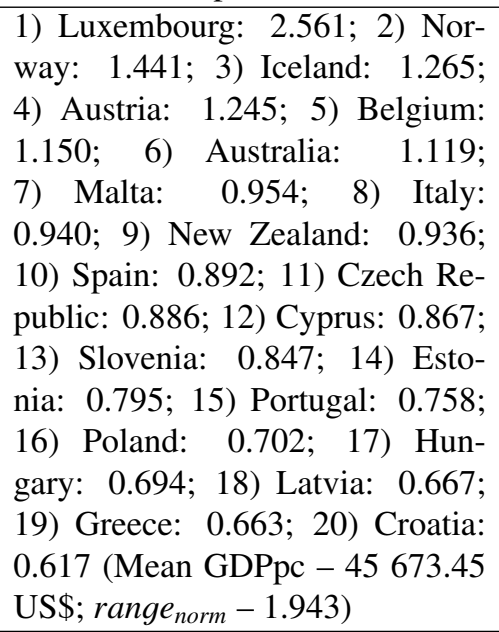 & 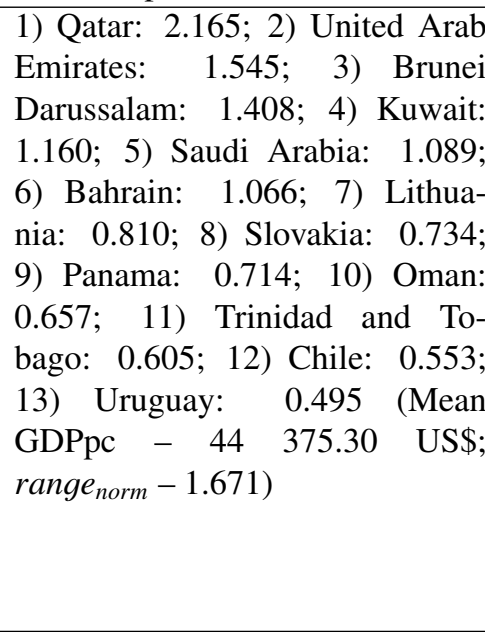 \\
\hline $\begin{array}{l}\text { Upper } \\
\text { middle- } \\
\text { income }\end{array}$ & $\begin{array}{l}\text { 1) Bulgaria: } 1.415 ; 2 \text { ) Costa Rica: } \\
\text { 1.227; 3) Thailand: } 1.139 ; 4 \text { ) Ser- } \\
\text { bia: } 1.096 \text {; 5) North Macedonia: } \\
\text { 1.030; 6) China: 0.965; 7) Geor- } \\
\text { gia: 0.905; 8) Armenia: 0.812; } \\
\text { 9) South Africa: 0.798; 10) Ja- } \\
\text { maica: 0.614 (Mean GDPpc }-16 \\
\text { 144.02 US\$; range } e_{\text {norm }}-0.801 \text { ) }\end{array}$ & $\begin{array}{l}\text { 1) Romania: } 1.637 ; 2) \text { Malaysia: } \\
\text { 1.556; 3) Mauritius: 1.256; } \\
\text { 4) Montenegro: 1.178; 5) Mex- } \\
\text { ico: 1.118; 6) Belarus: } 1.062 \text {; } \\
\text { 7) Lebanon: 0.873; 8) Colom- } \\
\text { bia: 0.829; 9) Brazil: 0.825; } \\
\text { 10) Bosnia and Herzegovina: } \\
0.821 ; 11 \text { ) Iran: 0.805; 12) Al- } \\
\text { bania: 0.763; 13) Peru: 0.719; } \\
\text { 14) Jordan: 0.558 (Mean GDPpc } \\
-18067.20 \text { US\$; range } \\
\text { 1.079) }\end{array}$ & 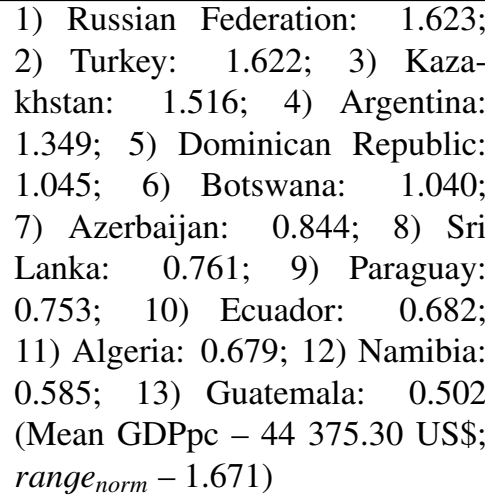 \\
\hline $\begin{array}{l}\text { Lower } \\
\text { middle- } \\
\text { income }\end{array}$ & $\begin{array}{l}\text { 1) Moldova: } 1.365 ; 2 \text { ) Ukraine: } \\
\text { 1.364; 3) Mongolia: 1.309; } \\
\text { 4) Tunisia: 1.183; 5) Philippines: } \\
\text { 0.941; 6) Vietnam: 0.839; 7) Mo- } \\
\text { rocco: 0.820; 8) India: 0.716; } \\
\text { 9) Kenya: 0.463 (Mean GDPpc- } \\
9251.03 \text { US\$; range } \text { norm }_{-}-0.902 \text { ) }\end{array}$ & $\begin{array}{l}\text { 1) Indonesia: 1.793; 2) El Sal- } \\
\text { vador: 1.358; 3) Cabo Verde: } \\
\text { 1.087; 4) Uzbekistan: 1.066; } \\
\text { 5) Honduras: 0.891; 6) Kyr- } \\
\text { gyzstan: 0.811; 7) Senegal: } \\
0.521 ; 8 \text { ) Zimbabwe: } 0.472 \text { (Mean } \\
\text { GDPpc-6 } 482.26 \text { US\$; } \text { range } \text { norm }^{-} \\
-1.321 \text { ) }\end{array}$ & $\begin{array}{l}\text { 1) Côte d'Ivoire: 2.814; 2) Egypt: } \\
\text { 1.653; 3) Bolivia: 1.249; 4) Lao } \\
\text { PDR: 1.098; 5) Ghana: 0.755; } \\
\text { 6) Nigeria: 0.749; 7) Myan- } \\
\text { mar: 0.722; 8) Pakistan: 0.678; } \\
\text { 9) Bangladesh: 0.647; 10) Cam- } \\
\text { bodia: 0.604; 11) Cameroon: } \\
\text { 0.523; 12) Zambia: 0.507 (Mean } \\
\text { GDPpc-7 037.83 US\$; range norm } \\
\text {-2.307) }\end{array}$ \\
\hline $\begin{array}{l}\text { Low- } \\
\text { income }\end{array}$ & $\begin{array}{l}\text { 1) Tanzania: } 1.583 ; 2 \text { ) Rwanda: } \\
\text { 1.281; 3) Madagascar: 0.986; } \\
\text { 4) Mozambique: 0.784; 5) Niger: } \\
\text { 0.728; 6) Malawi: 0.639 (Mean } \\
\text { GDPpc-1 } 674.18 \text { US\$; } \text { range }_{\text {norm }} \\
-0.945 \text { ) }\end{array}$ & $\begin{array}{l}\text { 1) Nepal: 1.340; 2) Tajikistan: } \\
\text { 1.331; 3) Mali: 0.940; 4) Uganda: } \\
\text { 0.875; 5) Burkina Faso: 0.874; } \\
\text { 6) Togo: 0.640 (Mean GDPpc }-2 \\
\text { 484.38 US\$; range } \text { norm }-0.700)\end{array}$ & $\begin{array}{l}\text { 1) Benin: 1.451; 2) } \text { Guinea: } \\
\text { 1.144; 3) Ethiopia: } 0.970 \text {; } \\
\text { 4) Yemen: } 0.434 \text { (Mean GDPpc- } \\
2228.56 \text { US\$; range } \text { norm }-1.017 \text { ) }\end{array}$ \\
\hline
\end{tabular}

GDP per capita, PPP in international US\$ is normalised by the formula $x_{i} / x_{\text {mean }}$ and sorted in descending order; income data source - the World Bank group, taken 2017-2019 average (2018 latest available for Yemen)

HEIs. The factor of the bankruptcy of travel companies and providers of various recreational services is the objective lack of demand for several months and the absence of a "financial safety cushion" - reserve funds in accounts that would help to freeze activities for about a year without losing assets. Moreover, tour operators often work on credit with final service providers (hotels, transport companies, insurers, etc.). In any case, they were forced to cover short-term accounts payable, unless it was possible to prove the fact of force majeure and if the terms of the contract directly indicated this point. In turn, the final (in the tourism product creation chain) suppliers had to settle accounts with their contractors, and even if they managed to reduce their receivables, unpaid invoices remained.

Despite the positive examples of innovation and profitable reorientation of traditional businesses, we do not agree with the thesis that analysts of a particular industry periodically express. It says that only enterprises un- 
able to realize new opportunities and offer existing loyal consumers a product adapted to new conditions have lost demand and income. Of course, the experts are partly right. However, it should be resolved that there are activities whose products cannot be completely converted into online or remote consumption. Virtual reality will not replace a tour, the key characteristic of which is direct physical contact with the natural environment, therapeutic climatic factors, objects of display, i.e. being in a specific geographic location. On the other hand, those companies that were temporarily out of work could compensate for some of their losses by providing other services to companies whose activities have not been suspended. For example, enterprises in the service sector, having teamed up with universities, could in a fairly short time create training courses for the MOOCs or a series of webinars, dividing the profits from their sale in emerging niches or using part of government transfers. Profits would be generated due to economies of scale, and the exchange of experience between specialists in the theoretical and practical fields of knowledge would increase the level of the intellectual capital of all participants. But only a few went this way, mainly those universities, which even before the crisis had established dual education. An obstacle for the rest, in addition to inertia, was the ban on the implementation of other activities, except those permitted by the statutory documents. If a travel company did not have the right to engage in educational or consulting services (in Ukraine and many other countries there is a severe restriction on the list of permitted types of business according to the Classifier of Economic Activities, which determines the policy of tax and financial reporting), then it actually could not qualify for payment consulting services during the creation of an educational project. If a simplified mechanism of interaction between stagnant and stable industries was developed for the quarantine period, part of the funds would be redistributed within such temporary contracts, which would reduce the pressure on social programs to support individual entrepreneurs and prevent unemployment. Of course, such cooperation mechanisms, which are contrary to current legal regulations, provide an opportunity for fraud, but dishonesty in commercial transactions is always characteristic of operational activities that do not meet an unambiguous, strictly defined set of procedures.

In the absence of communication with employers in the real labour market and total projected unemployment in "suspended" types of activities, universities that train specialists in professions unpopular in the new conditions begin to suffer losses. Psychologically, people are prone to immediate consumption and assessment of prospects according to the "here and now" principle, so many applicants will not choose a profession related to tourism and recreation in the next year or two (they do not reason logically that after the end of the quarantine period, demand for real, not virtual travel, will boost; and it will take at least three years to study for a bachelor's degree). At the level of regulatory bodies of the national education system (ministries and departments), it is necessary to provide alternatives to support temporarily unpopular specialities by the next academic year, using an interdisciplinary approach: it is possible to remove the existing legal restrictions on the curricula content in favour of a block of disciplines in a related knowledge branch so that the future student will have received the minimum necessary knowledge in the main speciality, and at the same time the basic block, which will allow him/her, in case of the bleakest prospects, to find a job in a related industry. For example, by combining the specialities of tourism and information technology (not necessarily classical programming, which requires excellent knowledge in the field of mathematical sciences and its inherent abstract thinking - on the contrary, you can focus on SEO, creation of multimedia products, Internet marketing), or tourism and finance (by making emphasis on planning and analysing indicators of intangible production and international financial transactions), it will be possible to somehow revive the popularity of the speciality, retain the scientific and pedagogical staff and reduce the influx of applicants to specialities with the highest competition and lack of vacancies. The question that is now more interesting for parents or guardians than for modern students - about formal qualifications according to the document on higher education. In the new conditions of the labour market, formal certificates began to lose relevance even in the pre-crisis period. Innovative companies and start-ups take into account the creative potential of the employee; his/her desire to develop in the chosen profession and the availability of real knowledge. The official diploma ceases to play a dominant role. This, by the way, has already led in recent years to the outflow of students with hypertrophied progressive views on the role of education and the ways of getting it from academic institutions towards professional courses and training in the company. If in the future, formal education for the current job position becomes mandatory, a person will be able to complete a master's degree, especially since migration between related fields of knowledge is allowed in many European countries, and universal programs are specially created. On the other hand, those who will study (as an experiment) on an interdisciplinary program, will become specialists of a wide profile able to bring new ideas and technologies to the industry and be more competitive in the labour market - especially in the current conditions that require the ability to adapt quickly.

\section{Changes in the organisation of tourism that lead to the emergence of new IT products}

The service industries are the most prone to market changes and must meet modern requirements for service providers as much as possible. The service sector, in particular the tourism industry, and the IT sector are interconnected through the development and use of a variety of software products and online applications that support the process of creating a tourism product. The difficulty in creating specialised software for tourism is necessary to ensure the widest possible integration and synchronisation in real-time of data streams coming from different providers, which, moreover, can often be located in different geographic regions. These are all kinds of services 
for booking accommodation and transport, accepting payments, including deferred payments and providing guarantees (freezing a share of funds on a client's account), insurance services - i.e. items included in a traditional basic allinclusive package. Nevertheless, new market conditions and the transition from organised to independent tours require the connection of many third-party resources and additional services, for example: search optimisation of the information about the provider of a single recreational service among hundreds of competitors (both on the Internet and in the database of sites-aggregators), automation of communication with existing and potential clients in social networks, preparation of media content (professional photos, audio and video) for posting on their sites and third-party resources, participation in exhibitions. The receiving region must provide not only a decent level of infrastructure - for example, correlate a load of public transport with popular tourist routes, but also equip vehicles with GPS receivers, develop and implement applications for tracking traffic along the route in real-time, simplify toll payments, one-time or by subscription, for foreigners, provide for the availability of alternative modes of transport and constantly monitoring the quality of their work and the maintained level of security. Engineering framework and distribution systems also require distinctive attention - if a significant increase in drinking water and electricity consumption is planned during the peak season, then it is imperative to simulate the loading of key nodes in advance to avoid failures and accidents at a time when even a one-day stop guarantees the sharp dissatisfaction of visitors and residents (and, accordingly, the decline in the reputation of the regional authorities and the recreational potential of the tourist region in general). The burden on the healthcare system, law enforcement bodies, etc. is increasing. The superstition, that all of the above issues become relevant only in case of real massive tourist flows in any closed territory, is incorrect. This is certainly true if the situation is modelled purely on the principle of spending additional resources - it is unreasonable to build a new airport or adapt domestic legislation in the field of, for example, health insurance, or change the operating mode of national banks and cancel restrictions on foreign exchange transactions for the sake of several hundred visitors a year. National economies with the largest share of the tourism industry in GDP are not simultaneously leaders in the absolute volume of tourism revenues, therefore, it occurs sometimes that the quality of the recreational infrastructure in the most visited popular countries is unsatisfactory, despite the recreation sector priority.

But an ill-conceived, outdated basic infrastructure at the primary level (information, communication with service providers) can create a persistent negative reputation, and even worse - maintain a complete information vacuum about the destination, so that, except for a few more daring tourists-pioneers, the region will never receive the minimum number of visitors that will raise the issue of attracting investments and updating the infrastructure.

Figure 1 shows the distribution of national economies according to the degree of tourism impact on GDP (initial data for 20 leading countries are shown in Table 4) [15].

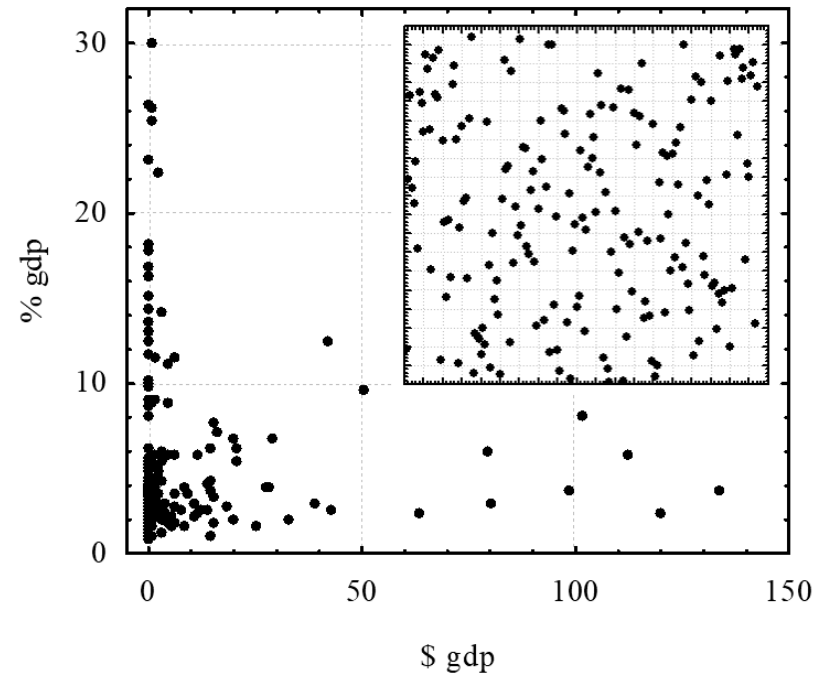

Figure 1. Scatterplots of the relative and absolute impact on GDP (on the internal graph, the spread is built by ranks, from 1 to 184 , by the number of countries studied (1st place is the best indicator))

Excluding a few countries (out of 184 in the row), all of them are grouped within the range of up to US\$ 150 bn of the absolute income of the tourism industry (direct impact to GDP), and the maximum share of tourism products in GDP, equal to $30 \%$.

If the distribution based on absolute income and the share of the tourism industry in GDP has certain characteristics, then the distribution based on the ordinal position on the ranking scale performs a completely disordered spread. The concentration of most of the studied national economies in the area of low absolute contribution to GDP with a more even distribution according to the percentage indicator proves that even with an increase in the volume of tourist flows, it is very difficult to obtain proportional GDP growth.

Of the 20 world leaders in terms of the relative contribution of tourism to GDP, only Macau and the Philippines were also included in the list of leaders in absolute terms (table 4). Moreover, in Macau, the tourism industry forms more than $50 \%$ of the national economy GDP, in the Philippines - more than $40 \%$. Therefore, countries do not try to make the tourism industry an explicit priority and do not abandon the production of other goods and services, except, of cause, those whose physical area and/or geographic location limits diversification. In the United States, Germany, China and Japan, tourism brings less than $3 \%$ of GDP, although in absolute terms the average figures for 2017-2019 were the highest in the world. Many researchers call tourism one of the most profitable sectors of the global economy but do not specify that there is a limit to income growth per unit of territory. The physical recreational capacity of the host region is limited, so traditional tourism based on physical site visits has rather tight growth margins. The territory of Macau is only about $30.8 \mathrm{~km}^{2}$ (for comparison, the area of Kyiv city is about $825 \mathrm{~km}^{2}$ [21]). 
Table 4. Direct Travel \& Tourism impact to GDP, selected countries (calculated as average for 2017-2019)

\begin{tabular}{|c|c|c|c|c|c|c|c|c|c|}
\hline 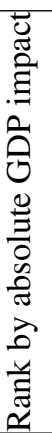 & Country & 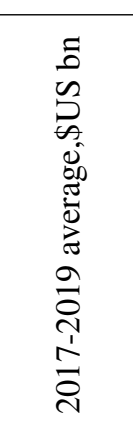 & 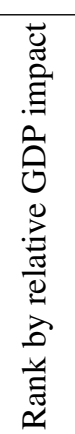 & 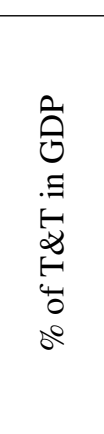 & 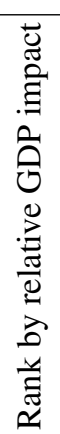 & Country & 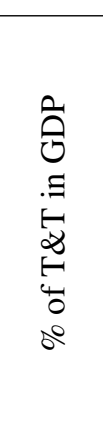 & 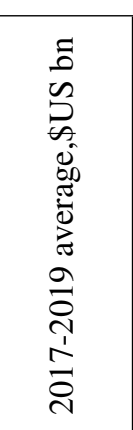 & 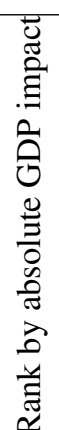 \\
\hline 1 & United States & 603.739 & 107 & 2.89 & 1 & Macau & 50.59 & 27.477 & 19 \\
\hline 2 & China & 364.971 & 114 & 2.75 & 2 & Aruba & 29.91 & 0.861 & 109 \\
\hline 3 & Germany & 134.025 & 87 & 3.53 & 3 & British Virgin Islands & 26.27 & 0.246 & 153 \\
\hline 4 & Japan & 120.159 & 131 & 2.37 & 4 & US Virgin Islands & 26.18 & 1.053 & 104 \\
\hline 5 & Italy & 112.268 & 50 & 5.64 & 5 & Maldives & 25.31 & 1.341 & 96 \\
\hline 6 & Mexico & 101.623 & 36 & 8.08 & 6 & Former Netherlands Antilles & 23.06 & 0.734 & 118 \\
\hline 7 & France & 98.618 & 81 & 3.71 & 7 & Bahamas & 22.33 & 2.947 & 72 \\
\hline 8 & United Kingdom & 80.660 & 106 & 2.90 & 8 & Grenada & 18.03 & 0.219 & 155 \\
\hline 9 & Spain & 79.563 & 45 & 5.87 & 9 & Seychelles & 17.76 & 0.279 & 149 \\
\hline 10 & India & 63.461 & 132 & 2.37 & 10 & St Lucia & 16.69 & 0.488 & 134 \\
\hline 11 & Thailand & 50.692 & 28 & 9.61 & 11 & Anguilla & 16.14 & 0.060 & 175 \\
\hline 12 & Brazil & 43.401 & 129 & 2.41 & 12 & Vanuatu & 15.01 & 0.137 & 167 \\
\hline 13 & Philippines & 42.286 & 19 & 12.44 & 13 & Antigua and Barbuda & 14.36 & 0.469 & 135 \\
\hline 14 & Australia & 39.693 & 104 & 2.92 & 14 & Cambodia & 14.04 & 3.552 & 61 \\
\hline 15 & Canada & 33.155 & 151 & 1.95 & 15 & Dominica & 13.63 & 0.073 & 173 \\
\hline 16 & Austria & 29.084 & 40 & 6.66 & 16 & Belize & 13.01 & 0.243 & 154 \\
\hline 17 & Saudi Arabia & 28.735 & 76 & 3.84 & 17 & Cape Verde & 12.97 & 0.247 & 152 \\
\hline 18 & Turkey & 27.795 & 80 & 3.73 & 18 & Sao Tome and Principe & 12.46 & 0.057 & 177 \\
\hline 19 & Macau & 27.477 & 1 & 50.59 & 19 & Philippines & 12.44 & 42.286 & 13 \\
\hline 20 & Russian Federation & 25.323 & 170 & 1.52 & 20 & Barbados & 11.64 & 0.557 & 129 \\
\hline
\end{tabular}

On the contrary, financial services, which Macau also specialises in, can be provided without the physical presence of the buyer; many transactions, especially trading in the stock markets, are conducted online. Therefore, this industry has almost unlimited growth, since the volume of generated final services does not depend on the area of the state territory. The essential difference exists between traditional types of tourism and other spheres of non-material production: the hard threshold of recreational capacity. If the software product (source code, file, etc.) is generated once and can be copied an infinite number of times, then the number of visitors can be increased solely based on the physical bandwidth of the destination. Countries that planned tourism revenues as a key factor in GDP growth did not always correctly assess recreational capacity. The virtualisation of travel services partially solves this problem, but not every traveller will agree to replace real impressions with artificial ones. Therefore, IT innovations in tourism based on "recreation without leaving home" are more of an auxiliary factor, rather than the main one (except for periods of isolation, as 2020 showed). But the virtual market is gradually growing and becomes difficult to be assessed correctly. Revenues from online events are recorded for a completely different type of economic activity, and it is possible to differentiate them according to the final consumption only using the data of the smallest sta- tistical unit - the company providing these services. That is, on the scale of the regional (even more difficult - national) economy, the income from virtual reality is estimated either purely empirically, or grounded at selective additional reporting of basic suppliers, which again raises the problem of building a reliable system of satellite accounts.

It would be wrong to say that organised tourism is rapidly becoming obsolete and the future is solely for individual travel. Large multinational companies will not just give up the high profits obtained, in fact, due to one-time large investments and subsequently repeated exploitation of almost durable resources, with a fairly simple business model and well-proven technological operations. They are now at the stage of transformation and testing of innovative technologies; even within the 2020 lockdown, many service establishments continued to operate. Those who manage to hold out until the restrictions on physical movement are lifted will benefit from the deferred demand effect. Fundamental changes in the global economic system led to the bankruptcy of thousands of tourism service providers operating according to the traditional scheme, but at the same time stimulated the implementation of innovations and the search for new forms of interaction with consumers in the context of the breakdown of the classic tourism organisation scheme. Those companies that were 
ahead of the curve not only saved profits and customers but, on the contrary, were able to get premium due to the virtual absence of competitors in the first periods of the industry lockdown. Cultural and leisure institutions that have already introduced virtual reality tours, digital information products, online access to their resources based on a considered (rational according to the consumer's opinion) and secure (taking into account the latest trends in ensuring the security of financial transactions) payment system have received an unprecedented flow of customers. The same can be attributed to the field of blogging and all kinds of training courses, which significantly increased the client base in record time in the conditions of information deprivation. On the one hand, there was a demand for new professions, together with a noticeable lack of specialists; short-term online training programs were massively created (unfortunately, not always by competent market participants) for the increasing demands of people who decided to change their field of activity. The relationship between the needs dictated by the tourism industry and IT developments has reached its zenith today.

It is logical to assume that a graduate of the Tourism speciality should have an idea of all the presented areas in general terms (at the level of understanding the mechanisms of interaction between suppliers of products at the stage of intermediate consumption, or the B2B segment), and ideally have practical skills in one of them almost at the level of a related profession representative (for example, be able to plan and implement SEO or draw up complete business plans using international financial standards). Unfortunately, this is very difficult to implement in the context of curricula formalisation of both specialities. Several selective disciplines of an introductory scope are not enough, and taking into account the normative reduction in the amount of classroom time on the minimum principle, it is almost impossible to supplement curricula to save funds for state universities in Ukraine. The current Methodological Recommendations for the implementation of ECTS in universities (the Order of the Ministry of Education and Science of Ukraine No. 1/9-119 of 02.26.2010) limits the number of classroom hours both per week and in terms of the total credits in the curriculum. The maximum of the allowed limit is very difficult to reach. For example, no more than 18 hours are allotted per week for master's training (an academic hour of 45 minutes is used, not the usual astronomical one). Theoretically, this limitation can be circumvented, but this procedure is rather complicated and expensive for educational institutions, therefore, state universities are forced to work exclusively within the Recommendations framework.

The situation in Bulgaria is somewhat better, although there are issues that would be better solved autonomously, at the level of universities, and not the Ministry of Education and Science (for example, the registration of foreign students, agreements concerning foreign practical studies, which is especially important for training in international tourism).

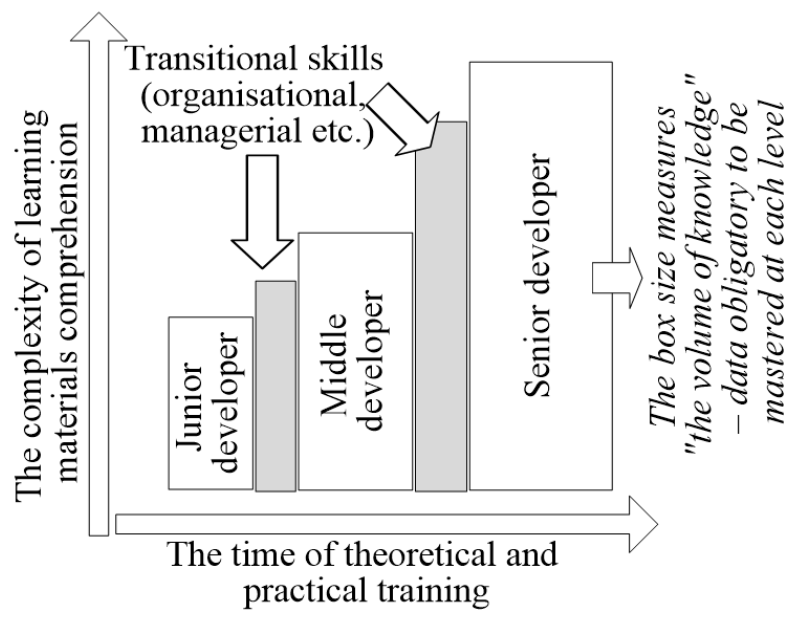

Figure 2. The "time-complexity" scale

\section{The tasks of the national education system and inclusive learning arising in response to global market challenges}

All these emerging tasks require the creation of new educational programs, which are increasingly acquiring the interdisciplinary character and, unfortunately, are rapidly becoming obsolete. This is due to the rapid updating of the IT solutions functionality used by travel companies. If we take an average training cycle of 3-4 years (at the college and university bachelor's level), adding another six months for mastering real skills in the workplace (we are talking about the development of competencies that allow a graduate to analyse the current situation within the external and internal environment of the company, to predict event scenarios and make managerial decisions - such skills are very difficult to acquire for a student who combines work with study), then we get on average 4-5 years for highquality training of a specialist in the service sector. At the same time, the average speed of updating versions of popular programs is $2-3$ times a year. It turns out that the basic course of HEIs, even with dual education, is not initially ready to prepare for the labour market an employee, who masters the most modern software products (except those studied in the last year). Obviously, a future specialist gets an understanding of the fundamental principles of the functioning of a certain area in academic classes, but he loses significantly to an employee who studies from scratch in the workplace. When planning curricula at the level of government agencies responsible for the development of a holistic concept of higher education (while not forgetting about school education, which is basic for complex personality development and the acquisition of cognitive functions), one should take into account the ratio between the amount of knowledge and skills required for start in a certain profession, and the speed of their assimilation (figure 2).

In programming, the approximate workers' classification includes three stages: the junior, middle and senior developer. These proficiency levels can not be reached simply by building up the knowledge in a particular field 
- there are so-called "grey" transition skills and competences, which should be accelerated. They include communication, managerial, organisational, linguistic and many other skills, that are out of the pure programming box, so a worker is usually not able to study them individually. Also, moving up the ICT career predisposes widening the spectrum of languages and technologies a person must know. It is the process of constant recirculation between different levels (perfect $\mathrm{C}$ knowledge will not substitute initial JavaScript skills if you do not know the syntax at all). IT demands on-going education and retraining. Indirectly, this process involves the end users of software products who need to adapt to new versions.

Despite breakthrough innovations in the natural sciences and the use of the latest equipment for research (at least in developed countries), it is impossible to prepare a practitioner capable of posing and solving complex problems in the field of biology, physics, chemistry in 2-3 years. And the formation of a scientific school requires at least $10-15$ years. Unfortunately, this process cannot be accelerated even with increased funding. The training period for practising specialists (taking into account the minimum period of accumulation of experience and adaptation in real working conditions after confirmation of formal education) in the field of medicine and some other areas of knowledge, mistakes of which can threaten the safety of human life or national security, is also 1015 years on average. It should be taken for granted that in a certain list of professions, the minimum accumulated experience is a decisive factor, and the return on investment in a specialist will not be obtained immediately. The modern market is now set for the shortest possible payback period. Over the past few decades, almost all countries - both developed and developing - have gone through a period of priority for "fast" specialities and sectors of the national economy. In each area, employers empirically build the rank of professions/positions/set of qualifications depending on the rate of theoretical knowledge accumulation and the transition to their practical implementation. Wages at the lowest level are cheaper, in most cases, only a minimum training period is needed, often limited to on-the-job instruction - and neither the company nor the state through the system of financing scholarship programs wants to train specialists of higher qualifications, or they train them in a minimum quantity, for specific positions. Of course, there are job positions with minimal requirements, but managers commit a big mistake if refusing to encourage employees to learn and advance higher, regardless of their age. The innovative potential of a company directly depends on the level of erudition (this is paramount since it is impossible to improve qualifications without understanding why it is needed and in what direction in general) and the qualifications of personnel. Saving now can lead to lost profits (worse, if real money losses) in the future. But even if the policy of inhouse training is supported in every possible way, some type of knowledge and skills always exist that can only be obtained from the outside - by exchanging experience with another company or formally training at the academic institution. The cumulative growth of knowledge of an in-

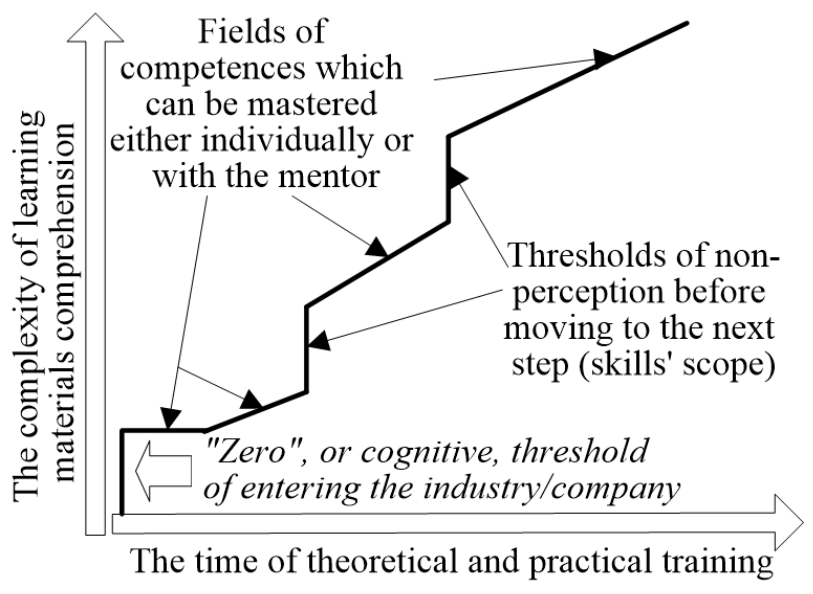

Figure 3. The thresholds of perception

dividual employee (or a university student) can be represented as a broken curve, very close to the previous graph (figure 3).

When a person just enters a new branch of knowledge/communication environment, the first threshold that he/she needs to overcome is cognitive immunity ("cognitive non-perception"). It is necessary to adapt the way of communication and perception of information for specific conditions, and if desired, it can be overcome individually or in an even shorter time - with the help of a coach or mentor. The first-year student or new employee then learns from the environment within the company (in terms of biology, the mini-habitat). After a few weeks or months, he/she has already been prepared, perfectly fulfils the current routine tasks and is ready to move on, expand the so-called comfort zone. Then the next threshold of non-perception appear, which cannot be overcome without acquiring professional knowledge, time to practice the new skills in practice and professional mentoring. Bypassing this threshold without the above-mentioned mandatory conditions (for example, an employee gets a higher position or expansion in the range of responsibilities for which he/she is not ready either morally or in terms of the totality of knowledge and skills) inevitably causes psychological discomfort between this person and colleagues who do not want to accept an obviously weak player into their team. In addition to improperly fulfilling new responsibilities, this employee simply cannot see new prospects for the company and options for introducing innovations and mires in routine work. Likewise, an industry, for which the labour market offers exclusively low and middle-level specialists, fails to find reserves for development. Experienced employees have learned how to quickly identify and solve current problems and maximally simplified current operations. The ability to think strategically, use an interdisciplinary approach is also a kind of skill, consisting of many competencies that cannot be formed below a certain level. Our study does not cover the psychological aspects and methods of motivation within the framework of this process, we state the result in the economic plane: the development of the company and the industry in gen- 
Table 5. Financing the national education system

\begin{tabular}{lcc}
\hline Main indicators & Bulgaria & Ukraine \\
\hline $\begin{array}{l}\text { Government expenditure on ed- } \\
\text { ucation, total (\% of government }\end{array}$ & 12,73 & 13,05 \\
$\begin{array}{l}\text { expenditure) } \\
\begin{array}{l}\text { Expenditure on tertiary educa- } \\
\text { tion (\% of government expendi- }\end{array}\end{array}$ & $15,92^{1}$ & 24,99 \\
$\begin{array}{l}\text { ture on education) } \\
\text { Government expenditure per } \\
\text { student, primary (\% of GDP per } \\
\text { capita) }\end{array}$ & $23.00^{1}$ & 30,32 \\
$\begin{array}{l}\text { Government expenditure per } \\
\text { student, tertiary (\% of GDP per }\end{array}$ & $16,60^{1}$ & 34,46 \\
$\begin{array}{l}\text { capita) } \\
\text { Literacy rate, adult total }(\% \text { of } \\
\text { people ages } 15 \text { and above) }\end{array}$ & $98,35^{2}$ & $99,97^{3}$ \\
\hline 2017 latest data, excluding ${ }^{1}: 2013 ;{ }^{2}: 2011 ;{ }^{3}: 2012$
\end{tabular}

eral, of the national economy as a set of industries based on the accumulation of knowledge and skills that stimulate the search for innovation, cannot be carried out without investment in intellectual capital and human resources. You can learn how to make perfect copies of business processes, but building the entire system of national education and production according to a franchise scheme is a preapproved lagging strategy. When adopting a strategy of continuous development, in addition to the initial investment in knowledge accumulation, it is necessary to budget for the losses from bad experiences and failure of innovations. The latter is often the decisive prohibitive criterion for the leaders of organisations and government agencies who decide to stop at a certain level of personnel development.

Losses for the state are not measured solely in material funds - these are social problems associated with unemployment of specialists whose skill level is high for the local market, or the need for a profession which will appear only in a few years, scientific projects that have not justified themselves, or support for unprofitable industries that lower their reputation for the international market, etc. According to the World Bank report [22], Ukraine occupies a leading position by the relative volume of higher education financing. But this indicator is further adjusted by the so-called "criterion of functionality" - the quality of the formal knowledge obtained and the ability to apply it in practice, i.e. get a job in a relevant speciality. The unfavourable situation in the labour market, as experts say, indicates the inefficiency of the education system, its inadequacy to market conditions. Table 5 shows the comparative characteristics of financial and some other indicators of Ukraine and Bulgaria [16].

Ukraine and Bulgaria spend about $13 \%$ of all government expenditure on education (mainly financing state educational institutions), but this amount is unevenly distributed further, between education levels. Bulgaria allocates only $16 \%$ of the budget for the tertiary education system when Ukraine spends $25 \%$ on HEIs. Accordingly, the unit costs per pupil (student) in Ukraine are 1.5-2 times higher than in Bulgaria. Nevertheless, as indicated earlier in table 2, both countries possess a very high literacy level of the population (in Bulgaria it is lower due to the part of migrating national minorities). On the other hand, having such high, in comparison with the world average, indicators of education, neither Bulgaria nor Ukraine provide data on the total population coverage with higher education, by various grades. Rather, such information can be obtained from the census data (which, according to the UN methodology, are carried out every 10 years and in 2020, of course, were suspended), specialised reports or national statistics services. The latter source is the most reliable, but if the indicators are not reflected in international statistical databases, then they are invisible to foreign experts who are used to focusing primarily on the world ratings, compiled by reputed international organisations. According to Ukrainian sources, in 2016-2018, the share of the country's population with a complete higher education (i.e., master's level and above) was about 30\% [22, 23], but these data were not displayed in the statistics of the World Bank, UNESCO or other international databases. Only Bulgaria in 2017 showed that about $24.7 \%$ of the population has a higher education at least of bachelor's level.

However, neither Ukraine nor Bulgaria was included in the popular ratings compiled by Index Mundi [24]. The reason, among other things, is the different approach to the classification of qualifications. In Ukraine, a bachelor's degree is traditionally not quoted among employers, and there is still no clarity in national legislation whether this level can be considered a complete higher education or the latter needs exclusively a master's level. The Law of Ukraine "On Higher Education" in the latest edition does not use the division into "basic" (bachelor) and "higher" (specialist, master) education at all, instead of distinguishing the first, second and third levels (bachelor, master, doctor of philosophy) - the grades common in most countries of the world. But the national statistical system has not yet fully switched to new standards, and the annual data on the number of university graduates are calculated without exact division by levels. Primary data are submitted by educational institutions and are closed to external users. The migration of the working-age population, which had sharply intensified in the last decade and was suspended by the lockdown, distorts the official census data since a complete socio-demographic cut is usually not carried out annually - this is too expensive and is not required for medium-term planning. In countries that massively accept unskilled labour from abroad, it is necessary to clarify the proportion of which population is taken into account when determining the level of education - exclusively citizens or temporary residents. Thus, it is difficult to obtain accurate data for comparing the effectiveness of higher education in different countries, and we would suggest introducing an additional adjustment factor for countries with a high proportion of foreign students (respectively, developed infrastructure of the education sector). Nevertheless, world practice separately measures the proportion of the population with the education of various levels, focusing on their stratification, and the generated ratings can affect the 
state's reputation in the system of global economic relations. More than that, the list of leading countries in terms of education levels does not coincide, although it would be logical to assume that a sufficient infrastructure for obtaining a bachelor's degree may predispose the local population to continue their studies - but this hypothesis is not confirmed.

Educational attainment, top 20 national economies (population 25+, cumulative total, \%), is as follows [24, based on 2015-2018 data]:

- at least Bachelor's or equivalent (within the list of 107 countries) - United Arab Emirates (46,56\%), Switzerland $(36,95 \%)$, United States $(34,99 \%)$, Belgium (34,69\%), Lithuania (34,54\%), Georgia (34,02\%), United Kingdom $(33,92 \%)$, Israel $(33,21 \%)$, Denmark $(32,36 \%)$, Australia $(31,75)$; Singapore $(31,6 \%)$, Ireland $(31,16 \%)$, Netherlands (31,09\%), Latvia (30,03\%), Cayman Islands $(29,86 \%)$, Korea $(28,68 \%)$, Cyprus $(28,56 \%)$, New Zealand $(28,1 \%)$, Norway $(28,07 \%)$, Saudi Arabia (25,98\%);

- at least Master's or equivalent (out of 99 countries) - Georgia (26,16\%), Switzerland $(23,78 \%)$, Slovak Republic (17,59\%), Czech Republic (17,53\%), Belgium $(16,87 \%)$, Tajikistan (15,58\%), Poland (15,52\%), Kyrgyz Republic (14,18\%), Denmark (12,97\%), Netherlands (12,9\%), Slovenia (12,86\%), United States $(12,84 \%)$, Albania $(12,82 \%)$, Spain $(12,81 \%)$, Peru $(12,75 \%)$, Israel (12,2\%), Austria (12,11\%), Cyprus (12,02\%), United Kingdom (11,97\%), Germany $(11,94 \%)$;

- doctoral or equivalent (among 85 countries) - Switzerland (2,93\%), Slovenia (2,76\%), United States $(2,03 \%)$, Israel $(1,44 \%)$, Germany $(1,25 \%)$, Sweden $(1,24 \%)$, Finland (1,14\%), Australia (1,14\%), Latvia (1,11\%), Norway (1,02\%), United Kingdom (1\%), Ireland $(0,99 \%)$, New Zealand (0,94\%), Austria (0,94\%), Puerto Rico $(0,93 \%)$, France $(0,84 \%)$, Cayman Islands $(0,81 \%)$, Denmark $(0,78 \%)$, Korea $(0,77 \%)$, Cyprus $(0,76 \%)$.

Only Cyprus, Denmark, Israel, Switzerland, the United Kingdom and the United States repeat in all three lists; this proves the continuity of the higher education cycles. In other countries, residents either stop at the bachelor's or master's level, and only a few proceed with the highest grade (to note, the Doctor of Science, actually the highest level, is not measured), or the population is roughly divided into two groups - those who graduate with the highest degree (at least master's) and the others not enrolled by higher education at all.

\section{Conclusions}

1. During periods of economic recession, each state faces the problem of redistributing budget funding in favour of the most profitable industries in the short run, to generate the required amount of foreign exchange earnings to avoid default. However, as the experience of many European countries demonstrates, ignoring the needs of the education sector, especially higher education, leads to social tension and a lack of motivation for effective work, which is especially important for young people.

2. Based on real statistical data, a contradiction between the postulate of the return growth on labour and an increase in the share of the working-age population with higher education is shown, explanations for this paradox are proposed, and it is noted that this problem arises in countries with high per capita income.

3. The tourism industry is starting to rely heavily on IT for professional applications, to support the basic workflow creating a package of services. For the coordinated work of enterprises of the two branches at the stage of intersectoral consumption, it is necessary to ensure the integration of curricula and apply an interdisciplinary approach in training specialists for the tourism industry, who must be proficient in information technology at an advanced level. Otherwise, the management system at travel companies will slow down the development of innovations.

4. Bulgaria and Ukraine have many common trends in the IT sector development, including the export earnings of IT products through outsourcing. Today Bulgaria is the leader in the field of tourism, Ukraine has a higher potential in the field of computer science and programming. Also, the studied countries have a different structure of tourist flows, which requires HEIs, which train professionals for the tourism industry, to have different content of educational programs.

5. In both Bulgaria and Ukraine, the intellectual potential in the IT sector works primarily for foreign markets, which deprives the local recreational infrastructure of reliable solutions developed based on regional specifics, in particular, restrictions on access to more expensive equipment, standard for developed countries.

6. The tendencies of using more expensive and highquality labour force to perform complex tasks in the IT sector may become a favourable incentive for technical universities in Bulgaria and Ukraine to train specialists and create more dual training programs, which, in turn, will stimulate employing companies to attract university graduates.

7. The service sector (within individual products and entire industries) is suggested to be divided into 1) a group with marginal reserves for creating added value per unit of resource, and 2) a group in which the growth potential is based on the duplication model of a single created product and therefore is limited only by the capacity of potential demand. Virtual travel services belong to the first group, while traditional recreational methods - to the second, and therefore the share of the tourism industry in GDP of many countries is insignificant. 
8. The process of building new teaching methods and techniques must necessarily date back to psychophysiological and social factors, the threshold of cognitive perception and motivation in mastering knowledge in innovative ways is especially important. In any branch of knowledge, there will remain areas that are amenable only to traditional formats, but their number is gradually decreasing - not due to technology development in general, but through the introduction of new means of interpersonal communication. The latter is the basis for overcoming restraining factors.

\section{References}

[1] M. Mysikova, J. Vecernik, Prague Economic Papers 28, 30 (2019)

[2] O. Dvouletý, Journal of Open Innovation: Technology, Market, and Complexity 5 (2019)

[3] K. Stefanova, N. Velichkov, South-Eastern Europe Journal of Economics 18, 115 (2020)

[4] F. Balázs, PORTA LINGUA 19, 19 (2019)

[5] K.N. Tang, Turkish Online Journal of Educational Technology 18, 1 (2019)

[6] T. Bolli, F. Pusterla, Is Technological Change Really Skills-Biased? Firm-level Evidence of the Complementarities between ICT and Workers' Education (2019)

[7] V. Lukesch, T. Zwick, Empirical Research in Vocational Education and Training 12, 1 (2020)

[8] T. Meyer, S. Thomsen, Are 12 Years of Schooling Sufficient for Preparation for Tertiary Education? Evidence from the Reform of Secondary School Duration in Germany, in Beiträge zur Jahrestagung des Vereins für Socialpolitik 2014: Evidenzbasierte Wirtschaftspolitik (ZBW - Deutsche Zentralbibliothek für Wirtschaftswissenschaften, LeibnizInformationszentrum Wirtschaf, Kiel und Hamburg, 2014), Number E13-V2 in Session: Labor Economics II, http://hdl.handle.net/10419/ 100305
[9] V. Vandenberghe, Ageing calls for shorter fulltime tertiary education and increased continuing education (2020), https://ssrn. com/abstract= 3520778

[10] A. Holzweber, Journal of Applied Languages and Linguistics 3, 68 (2019)

[11] H.W. You, International Journal of Emerging Technologies in Learning (iJET) 14, 203 (2019)

[12] A. Griva, C. Thanopoulos, S. Armakolas, Form@re - Open Journal per la formazione in rete 19, 175 (2019)

[13] R.A. Karim, A.H.M. Adnan, M.S.A.M. Salim, S. Kamarudin, A. Zaidi, 917 (2020)

[14] J.C.L. Chiang, S. Cheng, International Journal of Education, Psychology and Counseling 4, 251 (2019)

[15] World travel and tourism council, https://wttc. org

[16] World bank open data, https://data. worldbank. org

[17] N. Serheichuk, The best place for IT outsourcing: Bulgaria vs Ukraine, https://tinyurl . com/ 4 ex4w4uv

[18] The Country that Codes. IT Industry in Ukraine. 2019 Market Report, https://tinyurl.com/ 3mmmvt 86

[19] Global Talent Competitiveness Index 2020, https: //gtcistudy.com

[20] Global Innovation Index 2020, https: //www.wipo.int/global_innovation_index/ en $/ 2020 /$

[21] Kyiv city council, https://kyivcity.gov.ua

[22] Doslidzhennia sfery osvity $v$ Ukraini (Research of the education sphere in Ukraine), http://documents1.worldbank.org/curated/ en/790931568661644788/pdf/0verview.pdf

[23] Qualification map of ukraine, http://www. futureskills.org.ua/en/map

[24] Index mundi, https://www.indexmundi.com/ facts/indicators/ 